\title{
Electrochemical Degradation of Lignin by ROS
}

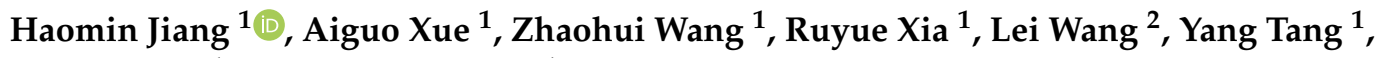 \\ Pingyu Wan ${ }^{1}$ and Yongmei Chen ${ }^{1, *}$
}

1 Institute of Applied Electrochemistry, College of Chemistry, Beijing University of Chemical Technology, Beijing 100029, China; haomin_jiang@163.com (H.J.); 2018210544@mail.buct.edu.cn (A.X.); 18811365389@163.com (Z.W.); 15610495891@163.com (R.X.); tangyang@mail.buct.edu.cn (Y.T.); pywan@mail.buct.edu.cn (P.W.)

2 Center for Advanced Materials Research, College of Materials and Chemical Engineering, Zhongyuan University of Technology, Zhengzhou 450007, China; wanglei@zut.edu.cn

* Correspondence: chenym@mail.buct.edu.cn

Received: 26 October 2020; Accepted: 8 December 2020; Published: 12 December 2020

\begin{abstract}
Lignin is a unique renewable aromatic resource in nature. In the past decades, researchers have attempted to breakdown the linkage bonds in lignin to provide aromatic platform chemicals that used to come from the petrochemical industry. In recent years, electrochemical lignin degradation under mild conditions has drawn much attention from the scientific community owing to its potential to scale up and its environmental friendliness. Sustainable electrochemical degradation of lignin consumes less energy and usually requires mild conditions, but low degradation efficiency and insufficient product selectivity are still significant challenges. The method for lignin degradation by reactive oxygen species (ROS) generated through the water oxidation reaction (WOR) at the anode and oxygen reduction reaction (ORR) at the cathode are more attractive for sustainable electrochemical degradation. The present contribution aims to review advancements in electrochemical degradation of lignin in aqueous or non-aqueous supporting electrolytes, focusing on the regulation of ROS in situ generated on the electrode.
\end{abstract}

Keywords: lignin degradation; electrochemical method; reactive oxygen species (ROS); water oxidation reaction (WOR); oxygen reduction reaction (ORR)

\section{Introduction}

At present, most of the carbon-containing bulk chemicals are transformed from non-renewable fossil resources, such as petroleum and coal, through a complicated conversion process, which brings a series of problems such as the greenhouse effect, climate change, and environmental pollution. According to the European Commission's report "World energy, technology and climate policy outlook 2030 (WETO)", the total world energy consumption would increase from 1.21 billion tons of oil equivalent (2010) to 1.45 billion tons of oil equivalent (2020), and up to 1.71 billion tons of oil equivalent by 2030. It is estimated that global carbon dioxide emissions will increase from $29.3 \times 10^{9}$ tons (2010) to $44.5 \times 10^{9}$ tons (2030), so the development and utilization of sustainable and renewable energy are imminent for contemporary people [1]. Lignin is the second most abundant component of lignocellulosic biomass after cellulose, and is the largest source of renewable aromatic compounds [2,3]. Therefore, a sustainable chemical industry based on lignin degradation to obtain aromatic platform chemicals has been proposed. Considering the complexity of the lignin molecular structure, the cleavage of the linkage bonds among the phenylpropane units during degradation is essential to improve product selectivity, which might simplify the subsequent separation process of the desired products [4-6]. Researchers have tried various methods, including pyrolysis, enzymatic processes, and chemical catalysis methods, to breakdown the linkage bonds in lignin [7-9], in which 
the degradation method with mild oxidant reagents (such as $\mathrm{O}_{2}, \mathrm{H}_{2} \mathrm{O}_{2}$ ) demonstrates good reaction selectivity in the cleavage of $\mathrm{C}-\mathrm{C} / \mathrm{C}-\mathrm{O}$ bonds $[10,11]$.

Electrochemical methods could be conducted under moderate conditions, such as relatively mild temperature, non-extreme pressure, and minimal needs for additional reagents. Lignin degradation by the electrochemical method has developed rapidly because of its controllable reaction and environmental friendliness. Researchers have tried to convert lignin to useful chemicals through oxidation on anode, reduction on the cathode or the combination of oxidation and reduction [12-14]. Several strategies have been proposed for the electrooxidative degradation of lignin: (1) the direct pathway that lignin is heterogeneously oxidized by an anode (for example, $\mathrm{Ni}[15,16], \mathrm{PbO}_{2}[17,18]$, or $\mathrm{RuO}_{2}$ [19]) as or a catalyst immobilized on the surface of the electrode; (2) the indirect pathway that lignin is homogeneously oxidized by anode-generated hydroxyl radicals $\left({ }^{*} \mathrm{OH}\right)$ through water oxidation reaction (WOR) at the anode or electrochemically recycled Red-Ox mediators (e.g., TEMPO [20,21], or NHPI [22,23]); and (3) the electrochemical-chemical combination pathway that lignin is oxidized by reactive oxygen species (ROS) generated at the electrode. Several ROSs, including hydroxyl radicals $\left({ }^{*} \mathrm{OH}\right)$, superoxide radical anions $\left({ }^{*} \mathrm{O}_{2}{ }^{-}\right)$, and hydrogen peroxide/hydrogen peroxide anion $\left(\mathrm{H}_{2} \mathrm{O}_{2} / \mathrm{OOH}^{-}\right)$, could be generated through WOR at the anode or ORR at the cathode under manipulated electrolysis conditions [24-26].

Recently, Deng's group provided a comprehensive review of electrochemical lignin conversion [27]. This review will be organized by the generation of ROS (Section 2), followed by degradation of lignin by ROS in aqueous electrolytes (Section 3) and in non-aqueous electrolytes (Section 4). The conclusions and prospects of electrochemical lignin conversion by ROS is mentioned at the end of this review.

\section{The Generation of ROS through WOR at the Anode}

There are three possible pathways for $\mathrm{H}_{2} \mathrm{O}$ molecules on anode: one molecule losing one electron to form ${ }^{*} \mathrm{OH}$ (1e-WOR, reaction R1); two molecules losing two electrons to form $\mathrm{H}_{2} \mathrm{O}_{2}$ (2e-WOR, reaction $\mathrm{R} 2$ ); and two molecules losing four electrons to form $\mathrm{O}_{2}$ (4e-WOR, reaction R3), which is referred to as the oxygen evolution reaction (OER) [28]. The redox potentials versus the normal hydrogen electrode (NHE) are marked as follows:

$$
\begin{gathered}
\mathrm{H}_{2} \mathrm{O} \rightarrow * \mathrm{OH}_{(\mathrm{aq})}+\left(\mathrm{H}^{+}+\mathrm{e}^{-}\right) \mathrm{E}^{0}=2.380 \mathrm{~V} \\
2 \mathrm{H}_{2} \mathrm{O} \rightarrow \mathrm{H}_{2} \mathrm{O}_{2}+2\left(\mathrm{H}^{+}+\mathrm{e}^{-}\right) \mathrm{E}^{0}=1.760 \mathrm{~V} \\
2 \mathrm{H}_{2} \mathrm{O} \rightarrow \mathrm{O}_{2}+4\left(\mathrm{H}^{+}+\mathrm{e}^{-}\right) \mathrm{E}^{0}=1.230 \mathrm{~V}
\end{gathered}
$$

Both ${ }^{*} \mathrm{OH}$ and $\mathrm{H}_{2} \mathrm{O}_{2}$ could be used in degradation of lignin due to their unique oxidizing abilities. In the aqueous solution, ${ }^{*} \mathrm{OH}$ groups exists on the anode surface in the form of chemical absorption, but their lifetime is limited. Thus, trying to produce $\mathrm{H}_{2} \mathrm{O}_{2}$ through the 2e-WOR process is considered to be a better choice $[29,30]$. To improve the selectivity of the 2e-WOR pathway, the practical approach is tuning the binding energies of the adsorbed oxygenic species $\left({ }^{*} \mathrm{OOH},{ }^{*} \mathrm{O}\right.$, and $\left.{ }^{*} \mathrm{OH}\right)$ on the electrode surface by choosing suitable electrochemical catalysts [31]. The moderate binding energy of hydroxyl intermediate $\left(\Delta \mathrm{G}^{*} \mathrm{OH}=1.76 \mathrm{eV}\right)$ is a benefit for the 2e-WOR pathway, because it is strong enough for the initial water adsorption but insufficient for $\mathrm{H}_{2} \mathrm{O}_{2}$ to escape from further oxidation. $\mathrm{BiVO}_{4}, \mathrm{CaSnO}_{3}$, and $\mathrm{ZnO}$ were reported as electrochemical catalysts for 2e-WOR [32-34], because the very weak ${ }^{*} \mathrm{OH}$ adsorption corresponding to the optimal free energy rarely occurs on other materials. Furthermore, owing to their wide bandgaps, these electrodes also serve as photoelectrochemical catalysts for $\mathrm{H}_{2} \mathrm{O}_{2}$ production. $\mathrm{BiVO}_{4}$ exhibited a high Faraday efficiency for producing $\mathrm{H}_{2} \mathrm{O}_{2}$ in a photo-electrocatalytic process, which benefits from the excellent matching between its bandgap and the redox potential of 2e-WOR [35]. Another important fact for improving the selective of 2e-WOR is the introduction of bicarbonate ions in the electrolyte, either in the electrocatalytic or photo-electrocatalytic process [36]. 


\section{The Generation of ROS through ORR at the Cathode}

The cathodic reaction process of an $\mathrm{O}_{2}$ molecule might go through three competing pathways: receiving one electron to form a ${ }^{*} \mathrm{O}_{2}{ }^{-}$(1e-ORR, reaction $\left.\mathrm{R} 4\right)$; receiving two electrons coupled with two protons to form a $\mathrm{H}_{2} \mathrm{O}_{2}$ (2e-ORR, reaction R5); and receiving four electrons coupled with four protons to form a $\mathrm{H}_{2} \mathrm{O}$ (4e-ORR, reaction $\left.\mathrm{R} 6\right)$ [37]:

$$
\begin{gathered}
\mathrm{O}_{2}+\mathrm{e}^{-} \rightarrow * \mathrm{O}_{2}^{-} \mathrm{E}^{0}=0.330 \mathrm{~V} \\
\mathrm{O}_{2}+2 \mathrm{H}^{+}+2 \mathrm{e}^{-} \rightarrow \mathrm{H}_{2} \mathrm{O}_{2} \mathrm{E}^{0}=0.670 \mathrm{~V} \\
\mathrm{O}_{2}+4 \mathrm{H}^{+}+4 \mathrm{e}^{-} \rightarrow \mathrm{H}_{2} \mathrm{O} \mathrm{E}^{0}=1.229 \mathrm{~V}
\end{gathered}
$$

Owing to the high compatibility and stability of ${ }^{*} \mathrm{O}_{2}{ }^{-}$in aprotic solvents, 1e-ORR could occur steadily in an aprotic solvent [38]. As a fact, the generated ${ }^{*} \mathrm{O}_{2}{ }^{-}$would rapidly transform to ${ }^{*} \mathrm{OOH}$ (R7) if certain protons exist, followed by accepting another electron from the cathode (R8) or reacting with another ${ }^{*} \mathrm{O}_{2}{ }^{-}$to form $\mathrm{OOH}^{-}$(R9) [39]. It means that the 1e-ORR pathway could convert to the 2e-ORR pathway just by introducing some protons into the supporting electrolyte. The same phenomenon has been observed by introducing some metal ion (such as $\mathrm{Mg}^{2+}$ ) into aprotic ionic liquids (ILs) [40]:

$$
\begin{gathered}
* \mathrm{O}_{2}^{-}+\mathrm{HA} \rightarrow * \mathrm{OOH}+\mathrm{A}^{-} \\
* \mathrm{OOH}+\mathrm{e}^{-} \rightarrow \mathrm{OOH}^{-} \\
* \mathrm{OOH}+* \mathrm{O}_{2}^{-} \rightarrow \mathrm{OOH}^{-}+\mathrm{O}_{2}
\end{gathered}
$$

In an aqueous solution or polymer electrolytes (protonic/alkaline ion exchange membrane), ORR mainly proceeds via 4e-pathway because of the thermodynamic advantage. However, the 2e-ORR pathway should be regulated for producing $\mathrm{H}_{2} \mathrm{O}_{2}$, from which several other ROS (including $\mathrm{OOH}^{-}$, ${ }^{*} \mathrm{OH}$ and ${ }^{*} \mathrm{O}_{2}{ }^{-}$) could be formed via ionization, oxidation and rearrangement in the electrochemical system (reaction R10-R12) [26]:

$$
\begin{gathered}
\mathrm{H}_{2} \mathrm{O}_{2} \rightarrow \mathrm{H}^{+}+\mathrm{OOH}^{-} \\
\mathrm{H}_{2} \mathrm{O}_{2}+\mathrm{HO}_{2}^{-} \rightarrow * \mathrm{OH}+* \mathrm{O}_{2}^{-}+\mathrm{H}_{2} \mathrm{O} \\
\mathrm{H}_{2} \mathrm{O}_{2} \rightarrow * \mathrm{O}_{2}^{-}+2 \mathrm{H}^{+}+\mathrm{e}^{-}
\end{gathered}
$$

As the reverse reaction of WOR, the selectivity of the ORR pathways also depends on the Gibbs free energy of the three adsorption intermediates mentioned above. Along this line, the suitable free energy of adsorbed hydrogen peroxide intermediate $\left(\Delta \mathrm{G}^{*} \mathrm{OOH}\right)$ is the key to control the selective two-electron oxidation of water molecules. On the other hand, to inhibit the oxygen evolution reaction, catalysts with an enormous binding energy of oxygenic species $\left(\Delta \mathrm{G}{ }^{*} \mathrm{O}\right.$ or $\left.\Delta \mathrm{G}{ }^{*} \mathrm{OH}\right)$ are necessary to impede 4e-ORR. Unfortunately, it is challenging to change $\Delta \mathrm{G} * \mathrm{OOH}$ without influencing $\Delta \mathrm{G}^{*} \mathrm{O}$ or $\Delta \mathrm{G}{ }^{*} \mathrm{OH}$ because there is an individual proportional relationship between these adsorption energies [41].

Recently, significant development has been achieved in the manipulation of the 2e-ORR process. It was reported that $\mathrm{Au}$ nanoparticles or $\mathrm{Au}(111)$ and $\mathrm{Au}(110)$ demonstrated good 2e-ORR reactivity with small overpotentials due to strong $\mathrm{O}_{2}$ adhesion in the surface of Au nanoparticles [42]. By controlling the size and shape of nanoparticles or the facets of $\mathrm{Au}$ or $\mathrm{Au}-\mathrm{Pd}$ nano-alloys, the selectivity of $\mathrm{H}_{2} \mathrm{O}_{2}$ reached $95 \%[43,44]$. Other studies focused on graphene and other carbon-based electrocatalysts to improve the selectivity of 2e-ORR $[45,46]$. It is worth noting that, due to the large ion volume, steric hindrance and solvation effect of IL, the 1e-ORR process could only steadily observed in aprotic ionic liquids (ILs) because of the stabilization of ${ }^{*} \mathrm{O}_{2}{ }^{-}$[47]. Additionally, the excellent reversibility of the $\mathrm{O}_{2} /{ }^{*} \mathrm{O}_{2}{ }^{-}$redox couple in aprotic IL acts as the fundamental for the metal ( $\mathrm{Na}$ or $\mathrm{Mg}$ )- $\mathrm{O}_{2}$ battery [48]. If the specific protonic agent is present in the aprotic $\mathrm{IL}$, then the formed ${ }^{*} \mathrm{O}_{2}{ }^{-}$might be protonated rapidly, while the protonated ${ }^{*} \mathrm{O}_{2}{ }^{-}\left({ }^{*} \mathrm{OOH}\right)$ proceeds another proton-coupled electron transferring 
processes to form $\mathrm{H}_{2} \mathrm{O}_{2}$ (electrochemical-chemical-electrochemical-chemical, ECEC mechanism) [49]. The above phenomenon implies that the type of ROS generated in situ through ORR in IL could be adjusted by manipulation of the electrolysis conditions, including the cathodic potential and protonic agent.

\section{Degradation of Lignin and Lignin Model Compounds by ROS Generated in Situ in Aqueous Electrolytes}

Electrochemical oxidation has been described as an effective alternative in wastewater treatment due to its mild treatment conditions and environmental friendliness [50]. Organics can be oxidized by the hydroxyl radicals $\left({ }^{*} \mathrm{OH}\right)$ and other active oxygen species produced during the electrochemical reaction $[51,52]$. In the early studies, the direct electrooxidation method was employed to degrade lignin in aqueous electrolytes, mainly in a strong alkaline medium, in which the ${ }^{*} \mathrm{OH}$ generated near the anode was the oxidizing agent $[53,54]$. Typical linkage bonds in lignin, such as $\mathrm{C}-\mathrm{C}$ bonds and $\mathrm{C}-\mathrm{O}$ bonds, were reported to be cleaved with appropriate potential.

Many studies employed dimensionally stable anodes (DSA, e.g., $\mathrm{IrO}_{2}$ [55], $\mathrm{PbO}_{2}$ [56], $\mathrm{SnO}_{2}$ [57]) to oxidize lignin through ${ }^{*} \mathrm{OH}$ generated on the anode surface. $\mathrm{IrO}_{2}$-based electrodes $\left(\mathrm{Ti} / \mathrm{SnO}_{2}-\mathrm{IrO} \mathrm{O}_{2}\right.$, $\mathrm{Ti} / \mathrm{RuO}_{2}-\mathrm{IrO}_{2}, \mathrm{Ti} / \mathrm{Ta}_{2} \mathrm{O}_{5}-\mathrm{IrO}_{2}$, and $\mathrm{Ti} / \mathrm{TiO}_{2}-\mathrm{IrO}_{2}$ ) were fabricated by overlaying the binary metal oxides on pretreated Ti substrates, and the $\mathrm{Ti} / \mathrm{RuO}_{2}-\mathrm{IrO}_{2}$ electrode showed the highest stability and the most increased activity for lignin degradation under $500 \mathrm{~mA} / \mathrm{cm}^{2}$, which was a large current that can be provided in the process of electrochemical degradation of lignin [12]. Additionally, $\mathrm{PbO}_{2}$-based electrodes were also applied in electrochemical degradation of lignin due to their high oxygen evolution potential $(+2.0 \mathrm{~V}$ vs. SCE). Moreover, electro-hydrogenation, as well as electrooxidation, were designed in the electrochemical reaction system, in which lignin was firstly oxidized and cleaved into intermediates through the oxidation of ${ }^{*} \mathrm{OH}$ formed by $\beta-\mathrm{PbO}_{2}$ crystal on the electrode surface. Afterwards, these intermediates went through the electro-hydrogenation process at the cathodes (such as $\mathrm{Ni}, \mathrm{Cu}, \mathrm{Cu} / \mathrm{Ni}-\mathrm{Mo}-\mathrm{Co}$, alloyed Steel, Ti/Cu/Sn). In the above system, vanillin, syringaldehyde, acetosyringone, 3-hydroxy-4-methoxyphenyl-ethanone, and 4-methoxy-3-methyl-phenol were obtained as the degradation products [18,53,58-61]. Recently, Movil-Cabrera et al. [14] prepared a Co core/Pt partial shell nanoparticle alloy anode coupled with a Pt ring cathode to electrochemically degrade lignin, suggesting that the ${ }^{*} \mathrm{OH}$ generated from water electrolysis. A suggested mechanism on the $\mathrm{Pb} / \mathrm{PbO}_{2}$ electrodes as follows:

$$
\begin{gathered}
\text { Co core/Pt partial shell anode: } \mathrm{H}_{2} \mathrm{O}-\mathrm{e}^{-} \rightarrow{ }^{*} \mathrm{OH}+\mathrm{H}^{+} \\
\text {Pt ring cathode: } \mathrm{H}_{2} \mathrm{O}+\mathrm{e}^{-} \rightarrow \mathrm{H}_{\text {ads }}+\mathrm{OH}^{-} \\
\text {Lignin degradation: } \mathrm{R}+{ }^{*} \mathrm{OH}+\mathrm{H}_{\text {ads-anode }} \rightarrow \mathrm{ROH}+\mathrm{R}^{\prime} \mathrm{H}
\end{gathered}
$$

It was reported that vanillin could be obtained by using $\mathrm{Ni}$ as anode under mild conditions [17]. The researchers investigated different shapes of Ni electrodes and found the apparent mass transfer coefficient was different. As shown in Figure 1, they found that the use of nickel electrodes with high surface area greatly enhanced the degradation percent of lignin under the same electrolysis conditions. Waldvogel et al. prepared a layer of electrochemical active $\mathrm{NiO}(\mathrm{OH})$ on $\mathrm{Ni}$ anode and used it to directly electrochemical oxidize lignin [62]. To increase the products selectivity on the Ni anode, a simple undivided high-temperature electrolytic cell for the electrooxidation of lignin at $160{ }^{\circ} \mathrm{C}$ has been designed recently. Under the optimized electrolysis conditions, the vanillin can be obtained with a yield of $4.2 \mathrm{wt} \%$, which in high selectivity with $67 \%$ efficiency compared to the common nitrobenzene oxidation [63]. 


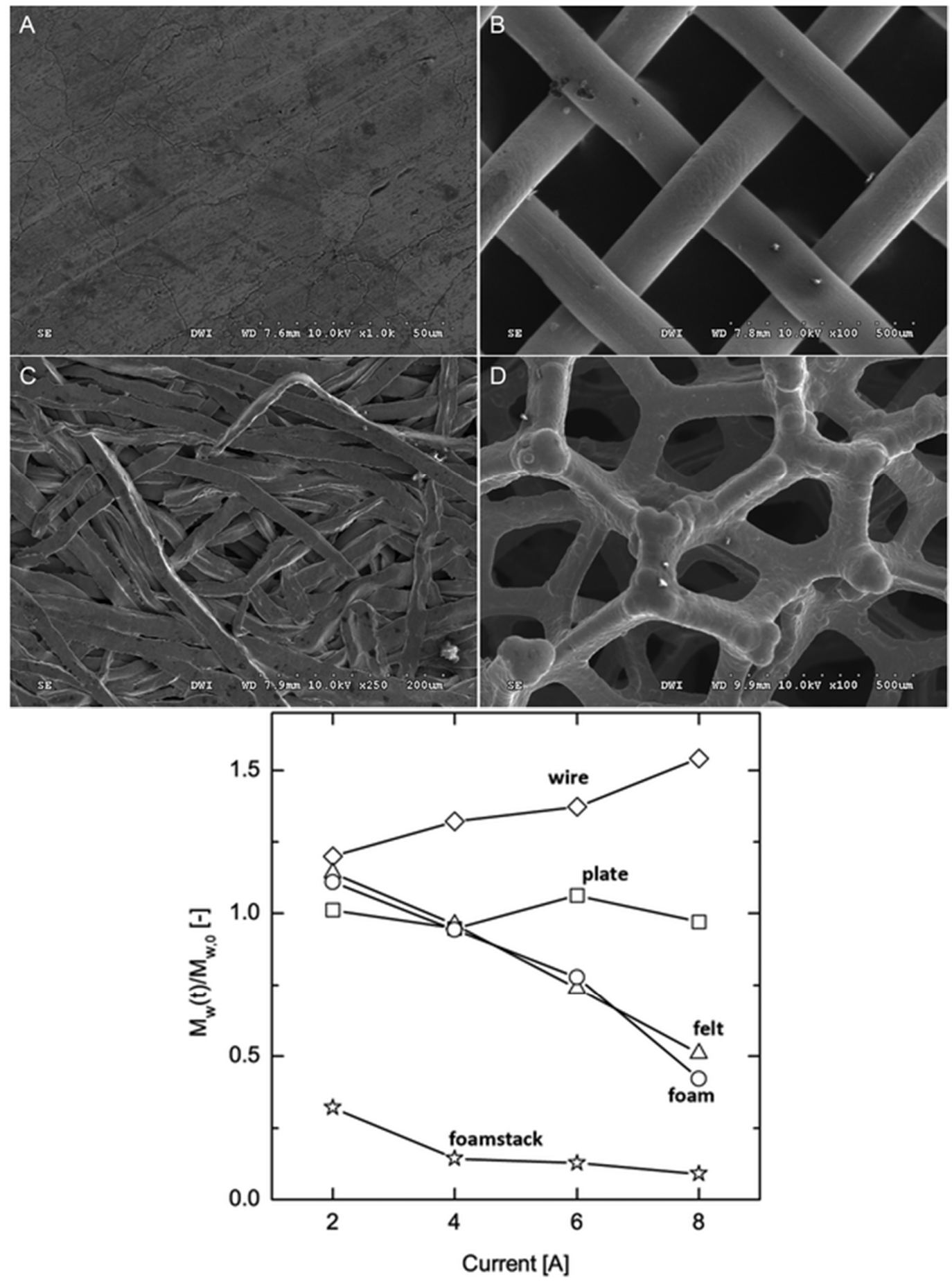

(E)

Figure 1. Nickel electrode morphologies in an electrochemical flow-through reactor. Materials are: (A) plate, (B) wire, (C) felt, and (D) foam. (E) The relative molecular weight of Kraft lignin after 90 min of electrochemical cleavage using different electrode materials and currents [17]. Copyright 2016, Royal Society of Chemistry.

However, the degradation of lignin through electro-generated ${ }^{*} \mathrm{OH}$ on the anode is accompanied by a strong oxygen evolution reaction (OER). As a competitive reaction, OER inhibits the charge transfer of lignin on the electrode surface, requires a higher voltage to be applied, and may have a more significant impact on electrode corrosion. Additionally, it is supposed to be attributed to over-oxidation of degradation products to organic acids and $\mathrm{CO}_{2}$. To prevent over-oxidation and achieve the enrichment 
of the target products, Wessling et al. [64] attempted to design a new type of electrochemical membrane reactor. Combined with the in situ nanopore filtration method, the electrochemical oxidation products of lignin were removed from the oxidizing environment to achieve the effect of sustainable electrolysis (see Figure 2). Separation of low-molecular-weight (LMW) products by a tubular ceramic nanoporous filtration (NF)-membrane was shown to double the number of products isolated from Kraft lignin.

a

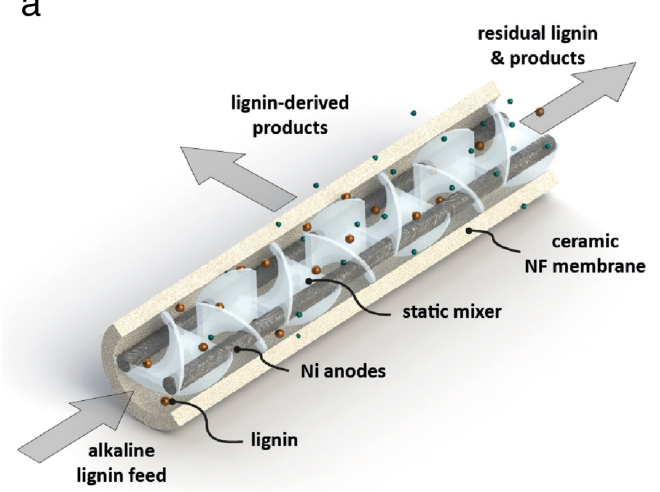

C

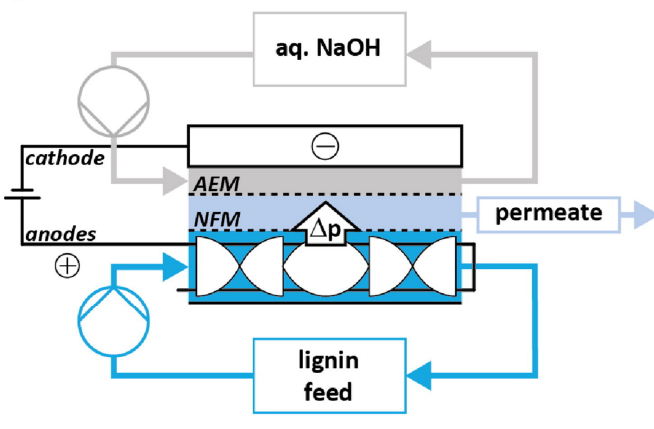

b

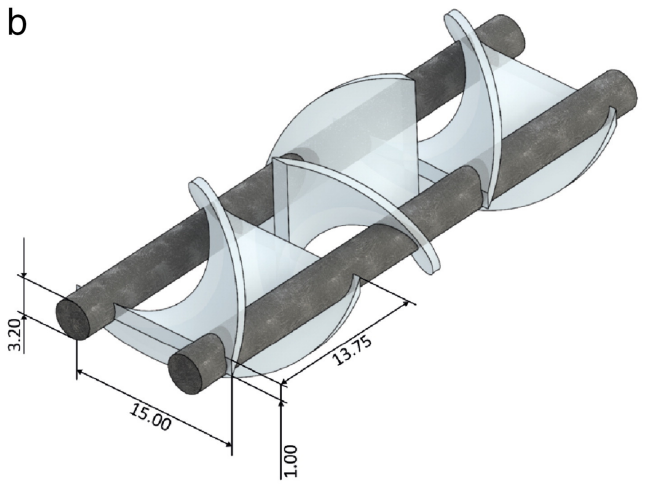

d

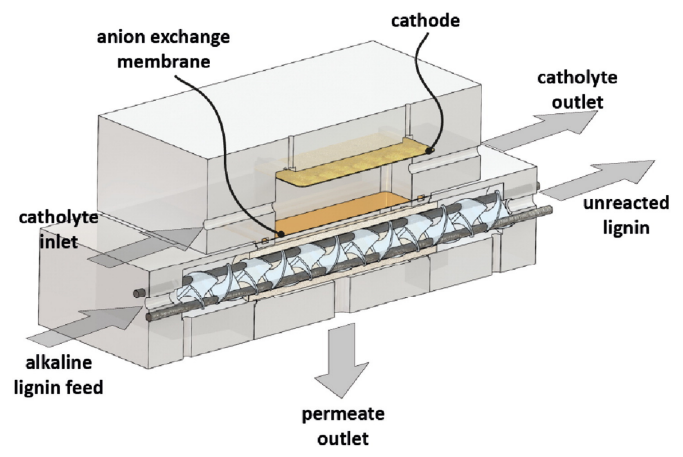

Figure 2. (a) Scheme of the electrochemical membrane reactor with in situ product removal for the electro-oxidative cleavage of lignin. (b) Detailed scheme of the electrode/mixer-unit, dimension are given in $\mathrm{mm}$. (c) Process scheme of the complete experimental setup (AEM: Anion exchange membrane; NFM: Nanofiltration membrane). (d) Cross-section of the module. The inside of the ceramic membrane is used as the reactor, the volume between the ceramic and the ion-exchange membrane is used for the collection of the permeate and the cathodic work is only used to close the electrical circuit [64]. Copyright 2015, Elsevier.

In our previous research, ROS generated through the ORR process in an aqueous solution was introduced to degrade lignin [65]. A non-membraned cylindrical electrolytic cell with the inner layer of graphite felt cathode and the outer layer of a mesh $\mathrm{RuO}_{2}-\mathrm{IrO}_{2} / \mathrm{Ti}$ anode with lignin in alkali solution as an electrolyte was designed (Figure 3A), in which led to $\mathrm{O}_{2}$ evolution on the anode and $\mathrm{O}_{2}$ reduction to form $\mathrm{H}_{2} \mathrm{O}_{2}$ on the cathode. The degradation products were extracted by diethyl ether and the yield was calculated by the weight of the extractant. The yield of lignin degradation products after electrolysis for $1 \mathrm{~h}$ in this non-membraned cell was $10.1 \%$, which was more than the sum of the yields in the anodic and cathodic chamber of a membrane cell ( $4.1 \%$ and $3.4 \%$, respectively). The result implied that a synergic effect existed between the anodic and cathodic electrode reaction. It seems that the electrolysis conditions for producing a higher concentration of $\mathrm{H}_{2} \mathrm{O}_{2}$ and $\mathrm{ROS}$ were in favor of giving higher yields of LMW products. In another study, 59.2\% of lignin was degraded into LMW products after 1 h-electrolysis at $80^{\circ} \mathrm{C}$ under a current density of $8 \mathrm{~mA} / \mathrm{cm}^{2}$ with extra $\mathrm{O}_{2}$. More than 20 kinds of lignin degradation products were identified, which originated from the over-oxidation during the degradation due to the strong oxidation capability of ${ }^{*} \mathrm{OH}$, generated through the decomposition 
of $\mathrm{H}_{2} \mathrm{O}_{2}$ (Figure 3B) [66]. On the other hand, the electric quantity in this electrochemical reactor is decreased comparing with the others $[53,54,57]$.

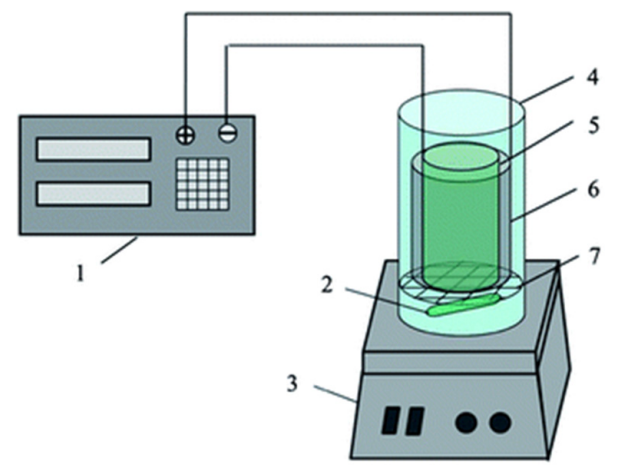

(A)

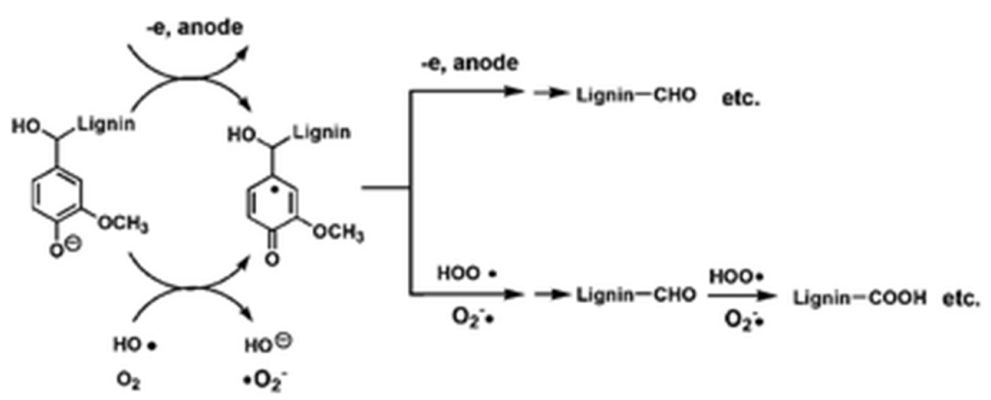

(B)

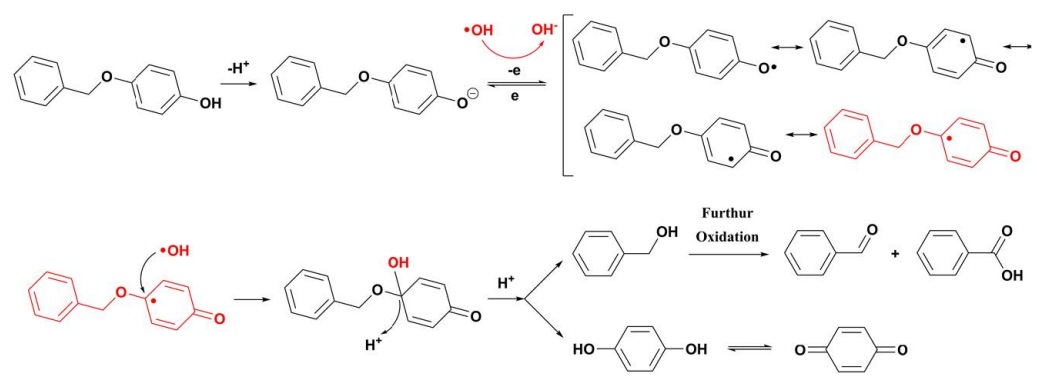

(C)

Figure 3. (A) A non-membraned cell for lignin degradation: (1) electrochemical workstation; (2) magneton; (3) magnetic stirrer; (4) electrolytic cell; (5) cylindrical inner layer graphite felt cathode; (6) cylindrical outer layer $\mathrm{RuO}_{2}-\mathrm{IrO}_{2 /} \mathrm{Ti}$ mesh anode; (7) electrode support [65]. Copyright 2014, Royal Society of Chemistry. (B) The possible pathways of lignin degradation by anode oxidation and electro-generated $\mathrm{H}_{2} \mathrm{O}_{2}$ oxidation [66]. Copyright 2014, Royal Society of Chemistry. (C) Scheme of PBP oxidative alkyl-O-aryl bond-cleavage [67]. Copyright 2017, Royal Society of Chemistry.

Several simple molecules with alkyl-O-aryl bonds, such as PBP (benzyl-O-phenol) and BPE (benzyl-O-phenyl), were used as lignin model compounds to study the mechanism of the bond cleavage during the electrolysis. By comparing the degradation yield and products of PBP and BPE, we deduced that the phenolic hydroxyl group in PBP might be the active site to be selectively attacked by ROS and finally trigger the cleavage of alkyl-O-aryl bond (as shown in Figure 3C). Based on several well-designed experiments, it was confirmed that the main ROS was ${ }^{*} \mathrm{OH}$. The degradation 
rate and product yield displayed a good positive linear relationship with the concentration of the electro-generated ${ }^{*} \mathrm{OH}$ on the ORR cathode [67]. This result indirectly proves that, compared with a single electrode, the synergistic effect of anode and cathode greatly increase the degradation efficiency of lignin.

\section{Degradation of Lignin and Lignin Model Compounds by ROS Generated in Situ in Ionic Liquids}

As alternative electrolytes, ionic liquids (ILs) are used in many electrochemical systems because of the unique properties such as wide electrochemical window, thermal stability, high conductivity, and low volatility $[68,69]$. Moreover, the electrochemical catalytic depolymerization of lignin in ILs has the following advantages: (1) ILs can improve the dissolution of lignin and its model compounds, thereby promoting the efficiency of electrocatalytic degradation; (2) under mild reaction conditions, different products selectivity and higher electrolysis efficiency can be obtained by applying different cell voltage on the electrode; (3) effectively inhibit OER or over oxidation of lignin, the current intensity generated in the electrochemical reaction process is directly proportional to the yield of intermediate or final products; and (4) avoid using harmful solvents and reagents to pollute the environment, while also reducing the energy consumption of separation and recovery processes. In 2010, Compton's group [70] firstly reported the electrochemical behaviors of several lignin model compounds in $\left[\mathrm{C}_{4} \mathrm{MIM}_{\mathrm{NTf}}\right.$, $\left[\mathrm{N}_{6,2,2,2}\right] \mathrm{NTf}_{2},\left[\mathrm{C}_{4} \mathrm{MIM}\right] \mathrm{OTf}$, and $\left[\mathrm{N}_{6,2,2,2}\right] \mathrm{OTf}$ by cyclic voltammetry $(\mathrm{CV})$ and abrasive stripping voltammetry methods, which confirmed the feasibility of electrochemical degradation of lignin in ILs.

Dier et al. [71] investigated the electrochemical degradation of lignin in the ionic liquids 1-ethyl-3-methylimidazolium trifluoromethanesulfonate ([EMIM]OTf) and triethylammonium methanesulfonate (TMS). The addition of water promoted hydrogen peroxide formation and significantly increased the yield of LMW products. In the 'water-contaminated' [emim][OTf] and TMS electrolytes, two pairs of redox peaks were shown in Figure 4 but disappeared in the pure [emim][OTf]. The oxidation peak A1 was attributed to the formation of ${ }^{*} \mathrm{OH}$, which can be further oxidized to $\mathrm{H}_{2} \mathrm{O}_{2}$ (peak A2) at the higher potential. This indicates that an attempt can be made to generate ROS in situ through anodizing in these electrolytes. At the applied voltage of $2.5 \mathrm{~V}$ in $24 \mathrm{~h}, \mathrm{TMS}-\mathrm{H}_{2} \mathrm{O}$ and [emim][OTf] $-\mathrm{H}_{2} \mathrm{O}$ exhibited electrochemical lignin degradation rates of $22 \%$ and $23 \%(w / w)$, respectively. It was found that in the electrolysis and proton transfer reactions, the presence of water (compared with the absence) displayed a significant impact on the degradation efficiency. Meanwhile, it was also found that the protic ionic liquid TMS is more beneficial to the electrocatalytic generation of $\mathrm{H}_{2} \mathrm{O}_{2}$.

PBP as the lignin model compound was electrolyzed using an ORR cathode in [BMIM]BF 4 (an aprotic IL), and the highest conversion rate of $83.6 \%$ for $4 \mathrm{~h}$ at a current density of $0.4 \mathrm{~mA} / \mathrm{cm}^{2}$ was observed (as shown in Figure 5A) [72]. The ORR process in [BMIM] $\mathrm{BF}_{4}$ was studied and the number of the transferring electrons was estimated to be 1.36 according to Laviron's theory, which implied that ${ }^{*} \mathrm{O}_{2}{ }^{-}$is the primary ROS generated through ORR in [BMIM] $\mathrm{BF}_{4}$. The reason is that the stability of ${ }^{*} \mathrm{O}_{2}{ }^{-}$could be improved in an aprotic solvent because the protonation and self-quenching reactions of radicals are suppressed. While the number of transferring electrons for ORR in the presence of PBP in [BMIM] $B_{4}$ was calculated to be 2.26 , which indicated that $\mathrm{H}_{2} \mathrm{O}_{2}$ became the main ORR products since PBP is a protonic agent. That is, the generated ${ }^{*} \mathrm{O}_{2}{ }^{-}$rapidly protonates to ${ }^{*} \mathrm{OOH}$, and then goes through another proton-coupled electron transferring process to form $\mathrm{H}_{2} \mathrm{O}_{2}$. It was found that the conversion rate increased dramatically when the trace amount of water was added into [BMIM] $\mathrm{BF}_{4}$ (see Figure 5B), which indicates that $\mathrm{H}_{2} \mathrm{O}_{2}$ is the main oxidizing agent to cleavage of alkyl-O-aryl bonds. Specifically, the conversion rate increases from $83.6 \%$ to $92.5 \%$ when $2.0 \%$ water was added, and reaches to $95.1 \%$ with the addition of $4.0 \%$ water. It is estimated that the faraday efficiency for the degradation of $\mathrm{PBP}$ in $\left[\mathrm{BMIM}^{\mathrm{B}} \mathrm{BF}_{4}\right.$ was about $7.3 \%$, which is not high enough. That may be attributed to the tardy transfer of $\mathrm{O}_{2}$ molecules in ILs onto the electrode surface and the energy loss during the two-step one-electron process to formation $\mathrm{H}_{2} \mathrm{O}_{2}$. 

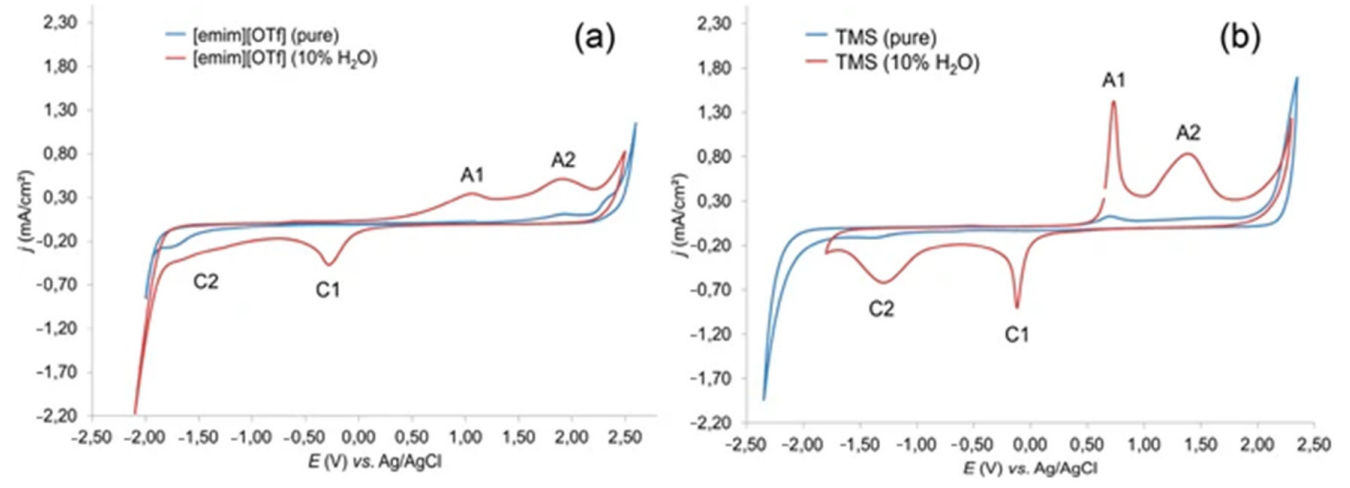

Figure 4. Cyclic voltammograms of pure (blue) and 'water-contaminated' (red) electrolytes (a) 1-ethyl-3-methylimidazolium trifluoromethanesulfonate ([Emim]OTf) and (b) triethylammonium methanesulfonate (TMS) [71]. Open access 2017, Springer Nature.

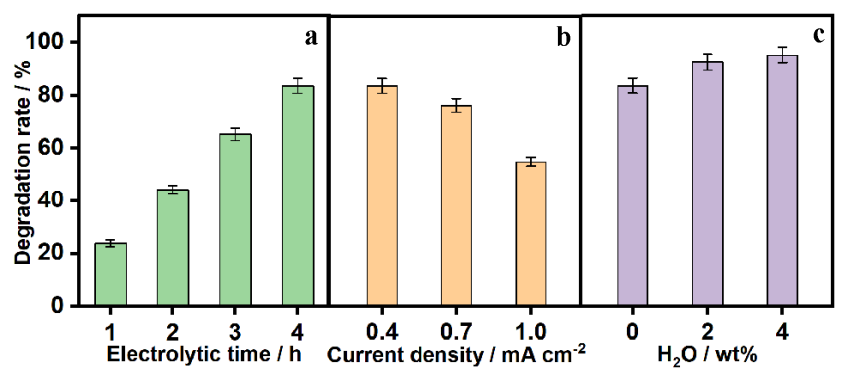

(A)

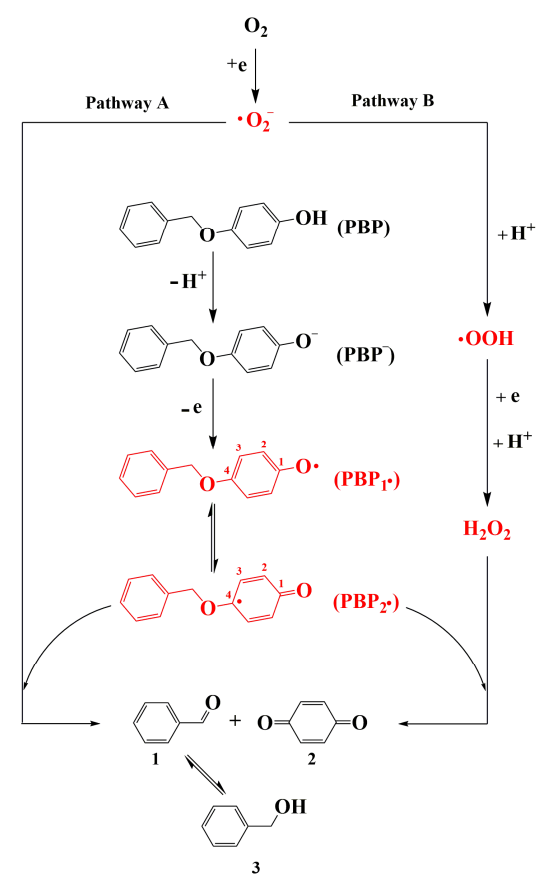

(B)

Figure 5. (A) The degradation rate of $\mathrm{PBP}$ in $[\mathrm{BMIM}] \mathrm{BF}_{4}$ under the electrolysis conditions of different electrolytic time (a), current densities (b) and water contents (c). (B) Scheme of ether bond cleavage by ROS generated in [BMIM]BF 4 [72]. Copyright 2018, IOP Publishing. 
We also studied the degradation of PBP in a protic ionic liquid [73]. The comparison of ORR process in $[\mathrm{BMIM}] \mathrm{BF}_{4}$ and $\left[\mathrm{NEt}_{3}\right] \mathrm{HSO}_{4}$ was shown in Figure 6, the anodic peak at $0.51 \mathrm{~V}$ (peak $1 \mathrm{a}$ ) and the cathodic peak at $-0.45 \mathrm{~V}$ (peak 1c) in both cases attributed to the oxidative reaction of PBP on the anode and the reductive reaction of the oxidation products of PBP, respectively. However, peak $2 \mathrm{a}$ and 3a which were revolved with ${ }^{*} \mathrm{O}_{2}{ }^{-}$disappeared in $\left[\mathrm{NEt}_{3}\right] \mathrm{HSO}_{4}$, indicating that hydrogen peroxide $\left(\mathrm{H}_{2} \mathrm{O}_{2}\right)$ was generated through the 2e-ORR process in the protic IL (see Figure 6).

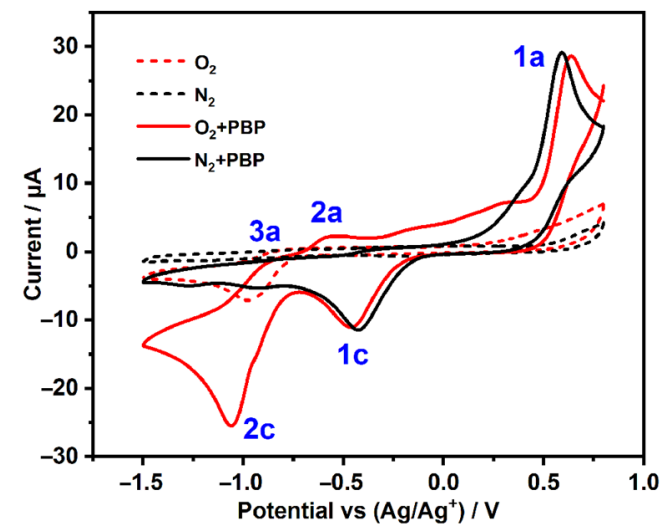

(A)

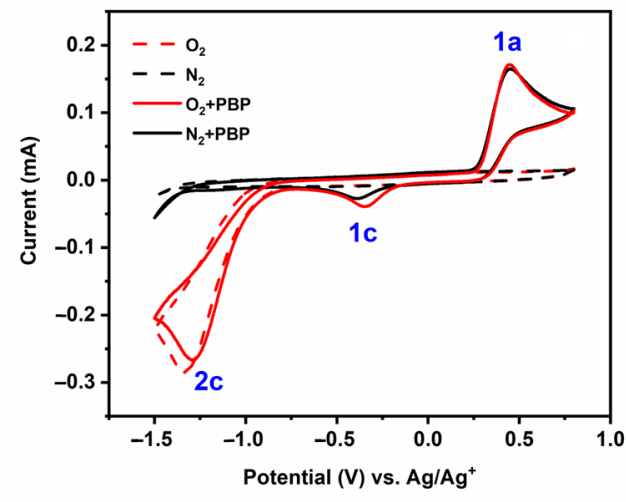

(B)

Figure 6. CV curves of glassy carbon electrode in [BMIM]BF 4 [72], Copyright 2018, IOP Publishing, (A) and [ $\left.\mathrm{NEt}_{3}\right] \mathrm{HSO}_{4}$ [73], Open access 2019, ESG. (B) In the absence and presence of $\mathrm{PBP}$ under $\mathrm{O}_{2}$ and $\mathrm{N}_{2}$ atmosphere at a scanning rate of $50 \mathrm{mV} \mathrm{s}^{-1}$.

After continuous electrolysis in protic ionic liquid $\left[\mathrm{NEt}_{3}\right] \mathrm{HSO}_{4}$ for $1 \mathrm{~h}$ under a current density of $1 \mathrm{~mA} / \mathrm{cm}^{2}$ at $20^{\circ} \mathrm{C}, 48.2 \%$ of PBP conversed and the faradaic efficiency was calculated as $29.5 \%$. The deduced mechanism is shown in Figure 7.

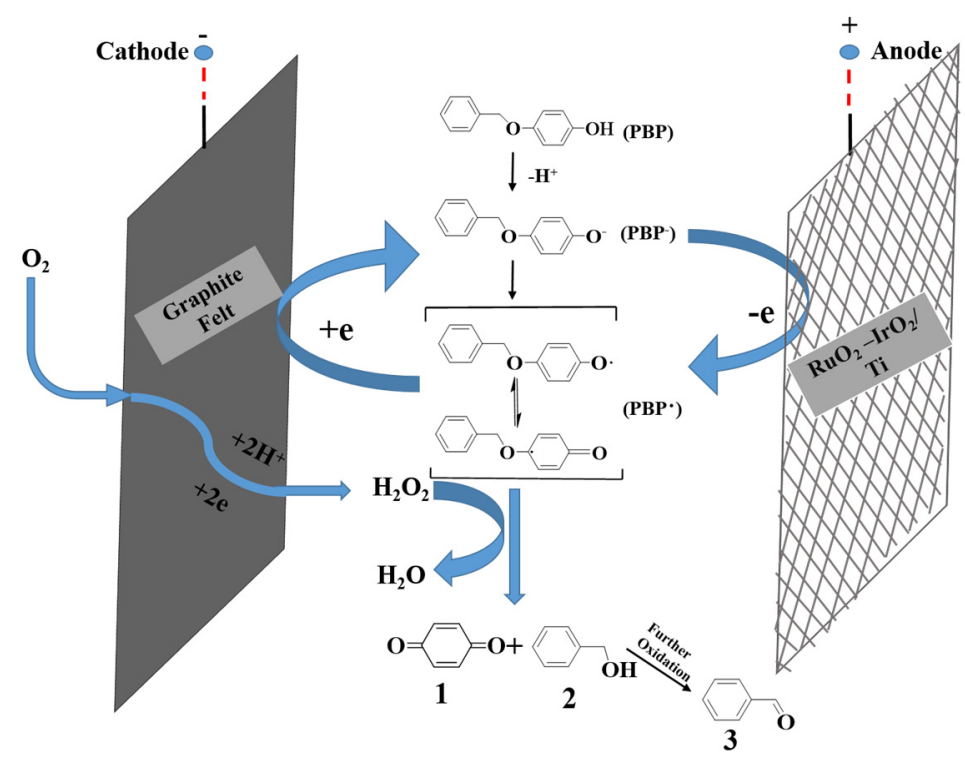

Figure 7. Scheme of the cleavage of ether-bond by $\mathrm{H}_{2} \mathrm{O}_{2}$ in $\left[\mathrm{NEt}_{3}\right] \mathrm{HSO}_{4}$ [73]. Open access 2019, ESG.

Recently, in order to verify the mechanism of bond cleavage of $\mathrm{C}_{\alpha}-\mathrm{C}_{\beta}$ bond or $\beta-\mathrm{O}-4$ bond in lignin by different kinds of ROS, GGE (guaiacylglycerol- $\beta$-guaiacyl ether) was chosen as a lignin model compound to be electrolysis using an ORR cathode in an aprotic ionic liquid ([BMIM]BF 4$)$. The results indicated that when the main $\mathrm{ROS}$ was ${ }^{*} \mathrm{OOH}$, coniferyl alcohol, guaiacol, and vanillin were detected 
as the degradation products which is supposed to follow $\beta-\mathrm{O}-4$ bond cleavage mechanism; Otherwise, when $\mathrm{OOH}^{-}$was the main ROS, coniferyl alcohol could not be detected and the degradation reaction path is assumed to follow $C_{\alpha}-C_{\beta}$ bond cleavage mechanism [74]. These results might provide more possibility to improve the product selectivity in the electrochemical lignin degradation by carefully controlling the electrolysis conditions.

The expensive of ILs causes concern about the recycling of ILs. Fortunately, the difference between ILs and the degradation products makes it possible to separate the products and recycle the ILs. In our previous study, [ $\left.\mathrm{NEt}_{3}\right] \mathrm{HSO}_{4}$ was re-used for electrolysis of lignin after the degradation products of lignin being extracted by diethyl ether and water being removed by rotary evaporation. Figure 8 shows the color of [ $\left.\mathrm{NEt}_{3}\right] \mathrm{HSO}_{4}$ was gradually darkened after re-used for several times due to a specific residue of lignin. The yield of degradation products in each cycle of electrolysis was $64.1 \%, 60.7 \%$, and $53.4 \%$, respectively.

The recently reported studies on electrochemical degradation of lignin or lignin model compounds are listed in Table 1. It is found that more extended time and higher voltage is required in the electrolysis by anodic oxidation. However, the competitive reaction of OER with the traditional alkaline solution system results in a lower degradation efficiency. Due to the non-selective mechanism of electrochemical degradation of lignin, in addition to electrochemical conversion rate, researchers are paying more and more attention to the yield of target products, such as vanillin, syringaldehyde, vanillic acid, and guaiacol. On the other hand, the current method for expressing the selectivity of lignin products cannot be unified. It suggests that electrochemical degradation of lignin by anodic oxidation to generated ${ }^{*} \mathrm{OH}$ needs longer time and higher current density, most of the conversion rate or current efficiency of these studies were not mentioned (No. 1, 2, 5, 8, 9 in Table 1). The lack of data indicates that the topic is not yet ripe for review. Different ORR cathodes such as graphite felt or C-PTFE gas diffusion electrode (GDE), and a variety of ROS synergistic degradation of lignin in ILs have been investigated, the efficiencies have been promoted to a different extent (No. 10, 11, 13, 14 in Table 1). The 1e-ORR or 2e-ORR processes in ILs could continuously produce ROS, which avoids consuming excess reagents or expensive metal catalysts. Too many protons might quench the ROS, and too less protons would not generate $\mathrm{H}_{2} \mathrm{O}_{2}$. It is worth noting that the number of protons in protic IL is appropriate to in situ electro-generated $\mathrm{H}_{2} \mathrm{O}_{2}$, which is the reason for the improved current efficiency.

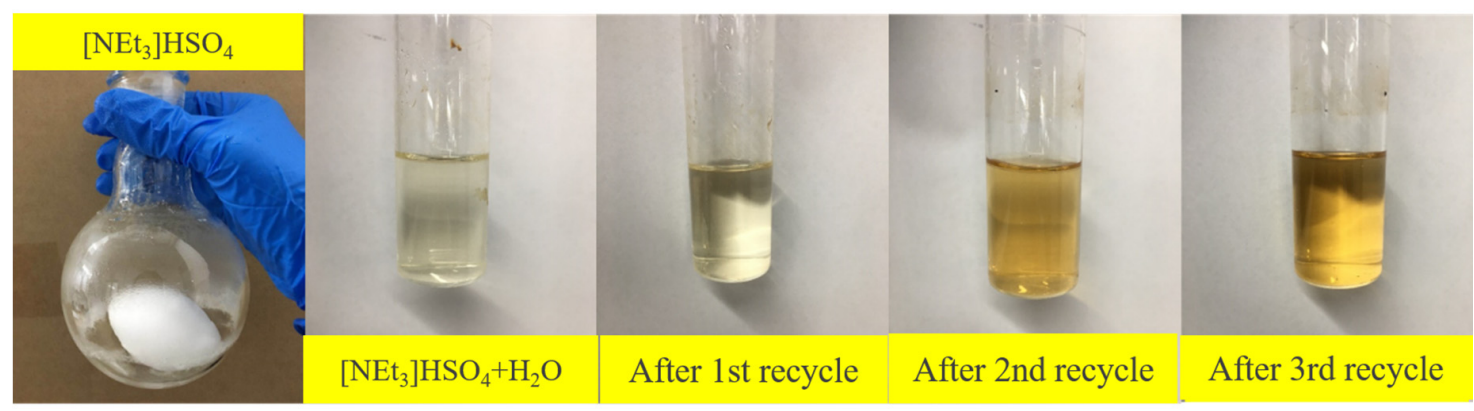

Figure 8. Digital photos of the $\left[\mathrm{NEt}_{3}\right] \mathrm{HSO}_{4}$ before and after different cycles of electrolysis (published for the first time). 
Table 1. The representative types of electrochemical degradation of lignin or lignin model compounds.

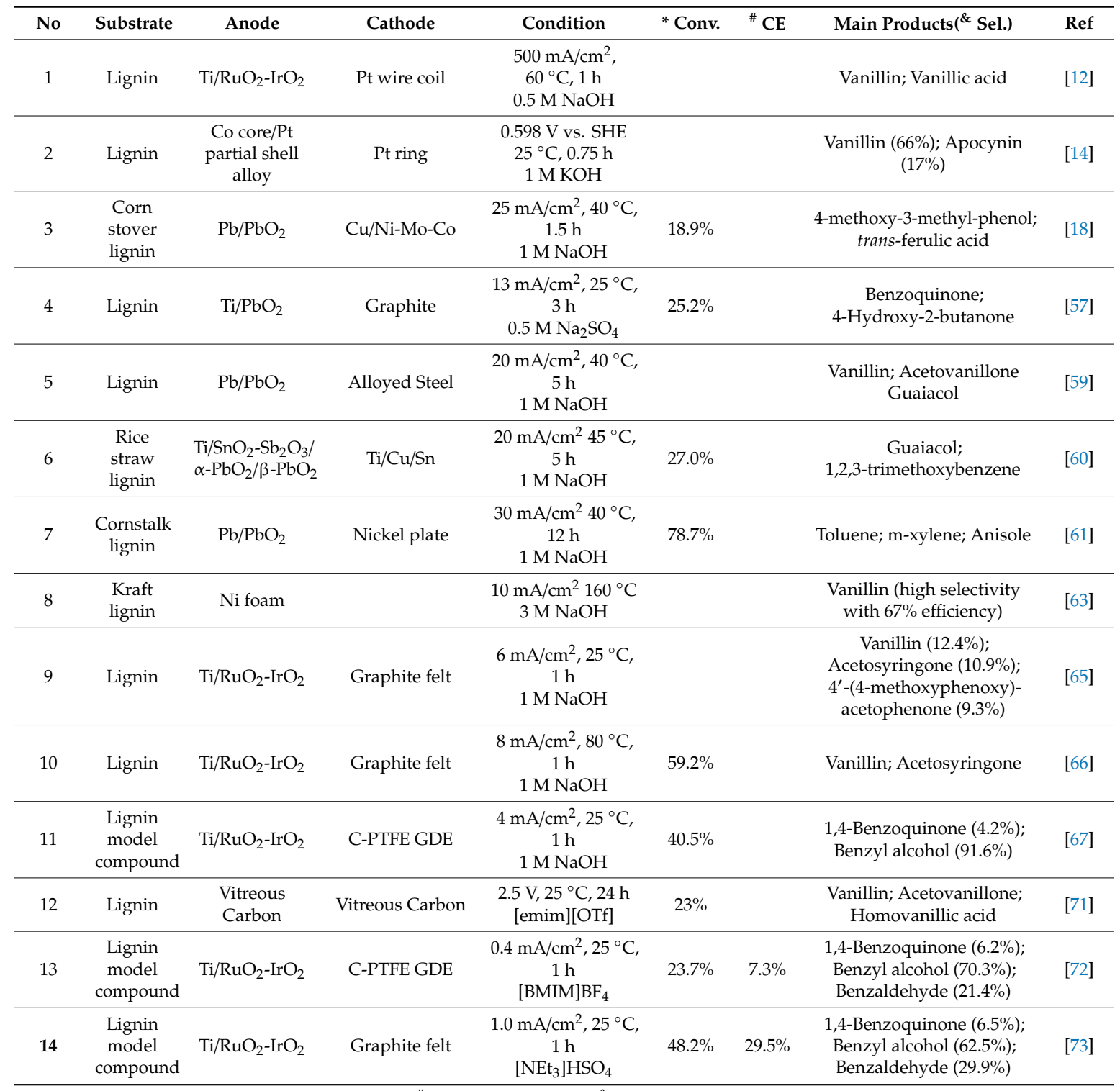

* Conversion rate; ${ }^{\#}$ Current efficiency; ${ }^{\&}$ Selectivity of main products.

\section{Concluding Remarks and Prospects}

In summary, lignin degradation by the generated ROS in situ through WOR and ORR processes provides the possibility to improve the degradation efficiency. Firstly, the different kinds of ROS could be generated through manipulating the electrolysis conditions of the WOR anode or ORR cathode, such as choosing the protic or aprotic supporting electrolyte. Secondly, the different kinds of ROS presents different reactive properties and might selectively attack the different linkages in lignin, resulting in good products selectivity. Thirdly, the current efficiency of lignin degradation in ILs is much better than that in aqueous electrolyte, since the lifetime of ROS is prolonged in ILs. Finally, the wide difference between the degradation products and ILs makes it possible to recycle ILs easily.

Nowadays, with the great efforts of scientists and the development of in situ analytical instruments, it is a great significance to reveal the complex reaction mechanism of electrochemical degradation of lignin for improving the selectivity and current efficiency of value-added chemicals. However, sustainable electrochemical degradation of commercial lignin still has a long way to go, due to the complex reactions on the electrode surface. We hope these results could lighten the application of electrochemical methods to degrade lignin to aromatic platform molecules in the near future. 
Author Contributions: Investigation and data curation: H.J., A.X., Z.W., R.X., L.W.; resources: Y.C. and P.W.; writing-original draft preparation: Y.C. and H.J.; writing—review and editing: Y.C., H.J., and Y.T. All authors have read and agreed to the published version of the manuscript.

Funding: China National Science Foundation (no. 22075012) and Beijing National Science Foundation (no. 2182046).

Acknowledgments: The authors would like to thank the funding agencies as described above for the financial support of this project. The authors thank Xinyue Zhang for valuable suggestions in the preparation of this manuscript.

Conflicts of Interest: The authors declare no conflict of interest.

\section{References}

1. Directorate-General for Energy Research; European Commission. Publication EUR 20366: World Energy, Technology and Climate Policy Outlook 2030 (WETO); Luxembourg Office for Official Publications of the European Communities: Luxembourg, 2003.

2. Upton, B.M.; Kasko, A.M. Strategies for the conversion of lignin to high-value polymeric materials: Review and perspective. Chem. Rev. 2015, 116, 2275-2306. [CrossRef] [PubMed]

3. Schutyser, W.; Renders, T.; Van den Bosch, S.; Koelewijn, S.-F.; Beckham, G.T.; Sels, B.F. Chemicals from lignin: An interplay of lignocellulose fractionation, depolymerisation, and upgrading. Chem. Soc. Rev. 2018, 47, 852-908. [CrossRef] [PubMed]

4. Di Marino, D.; Stöckmann, D.; Kriescher, S.; Stiefel, S.; Wessling, M. Electrochemical depolymerization of lignin in a deep eutectic solvent. Green Chem. 2016, 18, 6021-6028. [CrossRef]

5. Di Marino, D.; Aniko, V.; Stocco, A.; Kriescher, S.; Wessling, M. Emulsion electrooxidation of kraft lignin. Green Chem. 2017, 19, 4778-4784. [CrossRef]

6. Bawareth, B.; Di Marino, D.; Nijhuis, T.A.; Wessling, M. Unravelling Electrochemical Lignin Depolymerization. ACS Sustain. Chem. Eng. 2018, 6, 7565-7573. [CrossRef]

7. Li, C.; Zhao, X.; Wang, A.; Huber, G.W.; Zhang, T. Catalytic Transformation of Lignin for the Production of Chemicals and Fuels. Chem. Rev. 2015, 115, 11559-11624. [CrossRef]

8. Zhang, Z.; Song, J.; Han, B. Catalytic Transformation of Lignocellulose into Chemicals and Fuel Products in Ionic Liquids. Chem. Rev. 2017, 117, 6834-6880. [CrossRef]

9. Sun, Z.; Fridrich, B.; De Santi, A.; Elangovan, S.; Barta, K. Bright Side of Lignin Depolymerization: Toward New Platform Chemicals. Chem. Rev. 2018, 118, 614-678. [CrossRef]

10. Sippola, V.O.; Krause, A.O.I. Oxidation activity and stability of homogeneous cobalt-sulphosalen catalyst: Studies with a phenolic and a non-phenolic lignin model compound in aqueous alkaline medium. J. Mol. Catal. A Chem. 2003, 194, 89-97. [CrossRef]

11. Chen, Y.Y.; Xue, A.; Jiang, H.; Cheng, Y.; Ren, Y.; Sun, Y.; Chen, Y. A Two-phase Reaction System for Selective Oxidative Degradation of Lignin Model Compounds. BioResources 2020, 15, 6526-6538.

12. Tolba, R.; Tian, M.; Wen, J.; Jiang, Z.; Chen, A. Electrochemical oxidation of lignin at $\mathrm{IrO}_{2}$-based oxide electrodes. J. Electroanal. Chem. 2010, 649, 9-15. [CrossRef]

13. Garedew, M.; Young-Farhat, D.; Bhatia, S.; Hao, P.; Jackson, J.E.; Saffron, C.M. Electrocatalytic Cleavage of Lignin Model Dimers Using Ruthenium Supported on Activated Carbon Cloth. Sustain. Energy Fuels 2020, 4, 1340-1350. [CrossRef]

14. Movil-Cabrera, O.; Rodriguez-Silva, A.; Arroyo-Torres, C.; Staser, J.A. Electrochemical conversion of lignin to useful chemicals. Biomass Bioenergy 2016, 88, 89-96. [CrossRef]

15. Stiefel, S.; Marks, C.; Schmidt, T.; Hanisch, S.; Spalding, G.; Wessling, M. Overcoming lignin heterogeneity: Reliably characterising the cleavage of technical lignin. Green Chem. 2016, 18, 531-540. [CrossRef]

16. Stiefel, S.; Schmitz, A.; Peters, J.; Di Marino, D.; Wessling, M. An integrated electrochemical process to convert lignin to value-added products under mild conditions. Green Chem. 2016, 18, 4999-5007. [CrossRef]

17. Chen, F.; Lu, Z.; Tu, B. Electro-degradation of sodium lignosulfonate. J. Wood Chem. Technol. 2003, 23, 261-277.

18. Cai, P.; Fan, H.; Cao, S.; Qi, J.; Zhang, S.; Li, G. Electrochemical conversion of corn stover lignin to biomass-based chemicals between $\mathrm{Cu} / \mathrm{Ni}-\mathrm{Mo}-\mathrm{Co}$ cathode and $\mathrm{Pb} / \mathrm{PbO}_{2}$ anode in alkali solution. Electrochim. Acta 2018, 264, 128-139. [CrossRef] 
19. Reichert, E.; Wintringer, R.; Volmer, D.A.; Hempelmann, R. Electro-catalytic oxidative cleavage of lignin in a protic ionic liquid. Phys. Chem. Chem. Phys. 2012, 14, 5214-5221. [CrossRef]

20. Sannami, Y.; Kamitakahara, H.; Takano, T. TEMPO-mediated electrooxidation reactions of non-phenolic beta-O-4-type lignin model compounds. Holzforschung 2017, 71, 109-117. [CrossRef]

21. Rafiee, M.; Alherech, M.; Karlen, S.D.; Stahl, S.S. Electrochemical Aminoxyl-Mediated Oxidation of Primary Alcohols in Lignin to Carboxylic Acids: Polymer Modification and Depolymerization. J. Am. Chem. Soc. 2019, 141, 15266-15276. [CrossRef]

22. Kishioka, S.; Yamada, A. Kinetic study of the catalytic oxidation of benzyl alcohols by phthalimide-N-oxyl radical electro-generated in acetonitrile using rotating disk electrode voltammetry. J. Electroanal. Chem. 2005, 578, 71-77. [CrossRef]

23. Shiraishi, T.; Takano, T.; Kamitakahara, H.; Nakatsubo, F. Studies on electrooxidation of lignin and lignin model compounds. Part 2: N-Hydroxyphthalimide (NHPI)-mediated indirect electrooxidation of non-phenolic lignin model compounds. Holzforschung 2012, 66, 311-315. [CrossRef]

24. Zhang, Y.; Peng, Y.; Yin, X.; Liu, Z.; Li, G. Degradation of Lignin to BHT by Electrochemical Catalysis on $\mathrm{Pb} / \mathrm{PbO}_{2}$ Anode in Alkaline Solution. J. Chem. Technol. Biotechnol. 2014, 89, 1954-1960. [CrossRef]

25. Nonni, A.J.; Dence, C.W. The Reactions of Alkaline Hydrogen Peroxide with Lignin Model Dimers Part 3: 1,2-Diaryl-1,3-Propanediols. Holzforschung 1988, 42, 37-46. [CrossRef]

26. Agnemo, R.; Gellerstedt, G.; Leban, J.J.; Björkroth, U.; Rosell, S.; Folkers, K.; Yanaihara, N.; Yanaihara, C. The Reactions of Lignin with Alkaline Hydrogen Peroxide. Part II. Factors Influencing the Decomposition of Phenolic Structures. Acta Chem. Scand. 1979, 33, 337-342. [CrossRef]

27. Du, X.; Zhang, H.; Sullivan, K.P.; Gogoi, P.; Deng, Y. Electrochemical Lignin Conversion. ChemSuschem 2020, 13, 1-27. [CrossRef]

28. Shi, X.J.; Seoin, B.; Gill, T.M.; Siahrostami, S.; Zheng, X.L. Electrochemical Synthesis of $\mathrm{H}_{2} \mathrm{O}_{2}$ by Two-Electron Water Oxidation Reaction. Chem 2020, 7, 1-26. [CrossRef]

29. Shi, X.J.; Siahrostami, S.; Li, G.L.; Zhang, Y.R.; Chakthranont, P.; Studt, F.; Jaramillo, T.F.; Zheng, X.L.; Norskøv, J.K. Understanding activity trends in electrochemical water oxidation to form hydrogen peroxide. Nat. Commun. 2017, 8, 701. [CrossRef]

30. Siahrostami, S.; Li, G.L.; Viswanathan, V.; Nørskov, J.K. One- or two-electron water oxidation, hydroxyl radical, or $\mathrm{H}_{2} \mathrm{O}_{2}$ evolution. J. Phys. Chem. Lett. 2017, 8, 1157-1160. [CrossRef]

31. Dong, J.-C.; Zhang, X.-G.; Briega-Martos, V.; Jin, X.; Yang, J.; Chen, S.; Yang, Z.-L.; Wu, D.-Y.; Feliu, J.M.; Williams, C.T.; et al. In Situ Raman Spectroscopic Evidence for Oxygen Reduction Reaction Intermediates at Platinum Single-Crystal Surfaces. Nat. Energy 2019, 4, 60-67. [CrossRef]

32. Toma, F.M.; Cooper, J.K.; Kunzelmann, V.; McDowell, M.T.; Yu, J.; Larson, D.M.; Borys, N.J.; Abelyan, C.; Beeman, J.W.; Yu, K.M.; et al. Mechanistic insights into chemical and photochemical transformations of bismuth vanadate photoanodes. Nat. Commun. 2016, 7, 12012. [CrossRef] [PubMed]

33. Park, S.Y.; Abroshan, H.; Shi, X.; Jung, H.S.; Siahrostami, S.; Zheng, X. $\mathrm{CaSnO}_{3}$ : An electrocatalyst for 2-electron water oxidation reaction to form $\mathrm{H}_{2} \mathrm{O}_{2}$. ACS Energy Lett. 2019, 4, 352-357. [CrossRef]

34. Kelly, S.R.; Shi, X.; Back, S.; Vallez, L.; Park, S.Y.; Siahrostami, S.; Zheng, X.; Nørskov, J.K. ZnO as an active and selective catalyst for electrochemical water oxidation to hydrogen peroxide. ACS Catal. 2019, 9, 4593-4599. [CrossRef]

35. Zhang, K.; Liu, J.L.; Wang, L.Y.; Jin, B.J.; Yang, X.F.; Zhang, S.L.; Park, J.H. Near-Complete Suppression of Oxygen Evolution for Photoelectrochemical $\mathrm{H}_{2} \mathrm{O}$ Oxidative $\mathrm{H}_{2} \mathrm{O}_{2}$ Synthesis. J. Am. Chem. Soc. 2020, 142, 8641-8648. [CrossRef] [PubMed]

36. Fuku, K.; Sayama, K. Efficient oxidative hydrogen peroxide production and accumulation in photoelectrochemical water splitting using a tungsten trioxide/bismuth vanadate photoanode. Chem. Commun. (Camb.) 2016, 52, 5406-5409. [CrossRef] [PubMed]

37. Townshend, A. Standard Potentials in Aqueous Solutions. Anal. Chim. Acta 1987, 198, 333-334. [CrossRef]

38. AlNashef, I.M.; Leonard, M.L.; Kittle, M.C.; Matthews, M.A.; Weidner, J.W. Electrochemical Generation of Superoxide in Room-Temperature Ionic Liquids. Electrochem. Solid-State Lett. 2001, 4, D16. [CrossRef]

39. Andrieux, C.P.; Hapiot, P.; Saveant, J.M. Mechanism of Superoxide Ion Disproportionation in Aprotic Solvents. J. Am. Chem. Soc. 1987, 109, 3768-3775. [CrossRef] 
40. Schnaidt, J.; Nguyen, T.L.; Jusys, Z.; Behm, R.J. How Many Electrons Are Transferred during the Electrochemical $\mathrm{O}_{2}$ Reduction in a $\mathrm{Mg}^{2+}$-Free / $\mathrm{Mg}^{2+}$-Containing Ionic Liquid? Electrochim. Acta 2019, 299, 372-377. [CrossRef]

41. Calle-Vallejo, F.; Loffreda, D.; Koper, M.T.M.; Sautet, P. Introducing Structural Sensitivity into Adsorption-Energy Scaling Relations by Means of Coordination Numbers. Nat. Chem. 2015, 7, 403-410. [CrossRef]

42. Jirkovský, J.S.; Halasa, M.; Schiffrin, D.J. Kinetics of Electrocatalytic Reduction of Oxygen and Hydrogen Peroxide on Dispersed Gold Nanoparticles. Phys. Chem. Chem. Phys. 2010, 12, 8042. [CrossRef] [PubMed]

43. Zheng, Z.; Ng, Y.H.; Wang, D.-W.; Amal, R. Nanorods: Epitaxial Growth of Au-Pt-Ni Nanorods for Direct High Selectivity $\mathrm{H}_{2} \mathrm{O}_{2}$ Production. Adv. Mater. 2016, 28, 9949-9955. [CrossRef]

44. Jirkovský, J.S.; Panas, I.; Ahlberg, E.; Halasa, M.; Romani, S.; Schiffrin, D.J. Single Atom Hot-Spots at Au-Pd Nanoalloys for Electrocatalytic $\mathrm{H}_{2} \mathrm{O}_{2}$ Production. J. Am. Chem. Soc. 2011, 133, 19432-19441. [CrossRef] [PubMed]

45. Chen, Z.; Dong, H.; Yu, H.B.; Yu, H. In-situ electrochemical flue gas desulfurization via carbon black-based gas diffusion electrodes: Performance, kinetics and mechanism. Chem. Eng. J. 2017, 307, 553-561. [CrossRef]

46. Yang, W.; Zhou, M.; Cai, J.; Liang, L.; Ren, G.; Jiang, L. Ultrahigh yield of hydrogen peroxide on graphite felt cathode modified with electrochemically exfoliated graphene. J. Mater. Chem. A 2017, 5, 8070-8080. [CrossRef]

47. Zigah, D.; Wang, A.F.; Lagrost, C.; Hopoit, P. Diffusion of molecules in ionic liquids/ organic solvent mixtures. Example of the reversible reduction of $\mathrm{O}_{2}$ to superoxide. J. Phys. Chem. B 2009, 113, 2019-2023. [CrossRef] [PubMed]

48. Katayama, Y.; Onodera, H.; Yamagata, M.; Miura, T. Electrochemical Reduction of Oxygen in Some Hydrophobic Room Temperature Molten Salt Systems. J. Electrochem. Soc. 2004, 151, A59-A63. [CrossRef]

49. Khan, A.; Gunawan, C.A.; Zhao, C. Oxygen Reduction Reaction in Ionic Liquids: Fundamentals and Applications in Energy and Sensors. ACS Sustain. Chem. Eng. 2017, 5, 3698-3715. [CrossRef]

50. Chen, G. Electrochemical technologies in wastewater treatment. Sep. Purif. Technol. 2004, 38, 11-41. [CrossRef]

51. Nagpurkar, L.P.; Chaudhari, A.R.; Ekhe, J.D. Formation of industrially important chemicals from thermal and microwave assisted oxidative degradation of industrial waste lignin. Asian J. Chem. 2002, 14, 1387-1392.

52. Sun, X.; Sun, R.; Tomkinson, J.; Baird, M. Degradation of wheat straw lignin and hemicellulosic polymers by a totally chlorine-free method. Polym. Degrad. Stabil. 2004, 83, 47-57. [CrossRef]

53. Xu, H.; Yuan, Q.; Shao, D.; Yang, H.; Liang, J.; Feng, J.; Yan, W. Fabrication and characterization of $\mathrm{PbO}_{2}$ electrode modified with $\left[\mathrm{Fe}(\mathrm{CN})_{6}\right]^{3-}$ and its application on electrochemical degradation of alkali lignin. J. Hazard. Mater. 2015, 286, 509-516.

54. Pan, K.; Tian, M.; Jiang, Z.; Kjartanson, B.; Chen, A. Electrochemical oxidation of lignin at lead dioxide nanoparticles photoelectron-deposited on $\mathrm{TiO}_{2}$ nanotube arrays. Electrochim. Acta 2012, 60, 147-153. [CrossRef]

55. Trasatti, S. Electrocatalysis: Understanding the success of DSA. Electrochim. Acta 2000, 45, $2377-2385$. [CrossRef]

56. Liu, M.; Wen, Y.; Qi, J.; Zhang, S.; Li, G. Fine Chemicals Prepared by Bamboo Lignin Degradation through Electrocatalytic Redox between $\mathrm{Cu}$ Cathode and $\mathrm{Pb} / \mathrm{PbO}_{2}$ Anode in Alkali Solution. Chem. Select. 2017, 2, 4956-4962. [CrossRef]

57. Shao, D.; Liang, J.; Cui, X.; Xu, H.; Yan, W. Electrochemical oxidation of lignin by two typical electrodes: $\mathrm{Ti} / \mathrm{Sb}-\mathrm{SnO}_{2}$ and Ti/PbO 2 . Chem. Eng. J. 2014, 244, 288-295. [CrossRef]

58. Wang, Y.; Yang, F.; Liu, Z.; Yuan, L.; Li, G. Electrocatalytic degradation of aspen lignin over $\mathrm{Pb} / \mathrm{PbO}_{2}$ electrode in alkali solution. Catal. Commun. 2015, 67, 49-53. [CrossRef]

59. Chen, A.; Wen, Y.; Han, X.; Qi, J.; Liu, Z.; Zhang, S.; Li, G. Electrochemical Decomposition of Wheat Straw Lignin into Guaiacyl-, Syringyl-, and Phenol-Type Compounds Using $\mathrm{Pb} / \mathrm{PbO}_{2}$ Anode and Alloyed Steel Cathode in Alkaline Solution. Environ. Prog. Sustain. Energy 2018, 38, 13117-13126. [CrossRef]

60. Jia, Y.; Wen, Y.; Han, X.; Qi, J.; Liu, Z.; Zhang, S.; Li, G. Electrocatalytic degradation of rice straw lignin in alkaline solution through oxidation on a Ti/SnO $-\mathrm{Sb}_{2} \mathrm{O}_{3} / \alpha-\mathrm{PbO}_{2} / \beta-\mathrm{PbO}_{2}$ anode and reduction on an iron or tin doped titanium cathode. Catal. Sci. Technol. 2018, 8, 4665-4677. [CrossRef] 
61. Lan, C.; Fan, H.; Shang, Y.; Shen, D.; Li, G. Electrochemically catalysed conversion of cornstalk lignin to aromatic compounds: An integrated process of anodic oxidation of a $\mathrm{Pb} / \mathrm{PbO}_{2}$ electrode and hydrogenation of a nickel cathode in sodium hydroxide solution. Sustain. Energy Fuels 2020, 4, 1828-1836. [CrossRef]

62. Schmitt, D.; Regenbrecht, C.; Hartmer, M.; Stecker, F.; Waldvogel, S.R. Highly selective generation of Vanillin by anodic degradation of lignin: A combined approach of electrochemistry and product isolation by adsorption. Beilstein J. Org. Chem. 2015, 11, 473-480. [CrossRef] [PubMed]

63. Zirbes, M.; Quadri, L.L.; Breiner, M.; Stenglein, A.; Bomm, A.; Schade, W.; Waldvogel, S.R. High-Temperature Electrolysis of Kraft Lignin for Selective Vanillin Formation. ACS Sustain. Chem. Eng. 2020, 8, 7300-7307. [CrossRef]

64. Stiefel, S.; Lölsberg, J.; Kipshagen, L.; Möller-Gulland, R.; Wessling, M. Controlled depolymerization of lignin in an electrochemical membrane reactor. Electrochem. Commun. 2015, 61, 49-52. [CrossRef]

65. Zhu, H.; Chen, Y.; Qin, T.; Wang, L.; Tang, Y.; Sun, Y.; Wan, P. Lignin depolymerization via an integrated approach of anode oxidation and electro-generated $\mathrm{H}_{2} \mathrm{O}_{2}$ oxidation. RSC Adv. 2014, 4, 6232-6238. [CrossRef]

66. Zhu, H.; Wang, L.; Chen, Y.; Li, G.; Li, H.; Tang, Y.; Wan, P. Electrochemical depolymerization of lignin into renewable aromatic compounds in a non-diaphragm electrolytic cell. RSC Adv. 2014, 4, 29917-29924. [CrossRef]

67. Wang, L.; Chen, Y.; Liu, S.; Jiang, H.; Wang, L.N.; Sun, Y.; Wan, P. Study on the cleavage of alkyl-O-aryl bonds by in situ generated hydroxyl radicals on an ORR cathode. RSC Adv. 2017, 7, 51419-51425. [CrossRef]

68. Hou, Q.; Ju, M.; Li, W.; Liu, L.; Chen, Y.; Yang, Q. Pretreatment of Lignocellulosic Biomass with Ionic Liquids and Ionic Liquid-Based Solvent Systems. Molecules 2017, 22, 490. [CrossRef]

69. Xue, Z.; Qin, L.; Jiang, J.; Mu, T.; Gao, G. Thermal, electrochemical and radiolytic stabilities of ionic liquids. Phys. Chem. Chem. Phys. 2018, 20, 8382-8402. [CrossRef]

70. Chen, A.; Rogers, E.I.; Compton, R.G. Abrasive Stripping Voltammetric Studies of Lignin and Lignin Model Compounds. Electroanalysis 2010, 22, 1037-1044. [CrossRef]

71. Dier, T.K.F.; Rauber, D.; Durneata, D.; Hempelmann, R.; Volmer, D.A. Sustainable Electrochemical Depolymerization of Lignin in Reusable Ionic Liquids. Sci. Rep. 2017, 7, 5041. [CrossRef]

72. Wang, L.; Liu, S.; Jiang, H.; Chen, Y.Y.; Wang, L.N.; Duan, G.; Sun, Y.; Chen, Y.; Wan, P. Electrochemical Generation of ROS in Ionic Liquid for the Degradation of Lignin Model Compound. J. Electrochem. Soc. 2018, 165, H705-H710. [CrossRef]

73. Jiang, H.; Wang, L.; Qiao, L.; Xue, A.; Cheng, Y.; Chen, Y.Y.; Ren, Y.; Chen, Y.; Wan, P. Improved Oxidative Cleavage of Lignin Model Compound by ORR in Protic Ionic Liquid. Int. J. Electrochem. Sci. 2019, 14, 2645-2654. [CrossRef]

74. Jiang, H.; Cheng, Y.; Xue, A.; Bai, Z.; Tang, Y.; Sun, Y.; Wan, P.; Chen, Y. Degradation of a Lignin Model Compound by ROS Generated in-situ through Controlled ORR in Ionic Liquid. J. Electrochem. Soc. (in peer review).

Publisher's Note: MDPI stays neutral with regard to jurisdictional claims in published maps and institutional affiliations.

(C) 2020 by the authors. Licensee MDPI, Basel, Switzerland. This article is an open access article distributed under the terms and conditions of the Creative Commons Attribution (CC BY) license (http://creativecommons.org/licenses/by/4.0/). 